\title{
Food Diversification in Java
}

\author{
Roeskani Sinaga ${ }^{1}$, Manuntun Parulian Hutagaol ${ }^{2}$, Sri Hartoyo ${ }^{3}$, Nunung \\ Nuryartono ${ }^{4}$ \\ 1Doctoral Program in Economics of Agriculture, IPB, Indonesia \\ 2,3,4Faculty of Economics and Management, IPB, Indonesia \\ Email: roeskani@gmail.com
}

\begin{abstract}
Consumption system closely related to food diversification. Economic structure diversity, income level diversity, household food price level. This paper analyses the food diversification in Java. Household is categorized based on the income level to analyze the food diversification level of every category. Households that income level are in Q3 \& Q4 have lower food diversification compared to the ones who are in level Q1 and Q2. Expense level of every household per capita is not always associated by reaching the calory achievement $2.150 \mathrm{kkal}$ per day. The result of a research shows that the Berry Index (BI) is lower than Modified Berry Index (MBI) both in rural and urban. That result of the research shows that $\mathrm{BI}$ and $\mathrm{MBI}$ is close to 1 that means the households diversification level is high. The household income growth of Q1 and Q2 doesn't improve the food diversification (Dependent Variable BI). While the household income growth of Q3 and Q4 improve the food diversification (Dependent Variable BI). The price of food commodity affects the changes of food diversification. The increasing of household members will decrease the food diversification (Household Q1), while the increase of household members improves the food diversification of household Q2, Q3, and Q4. Household diversification in urban is higher than rural.
\end{abstract}

Keywords: Diversification, Berry Index (BI), Modified Berry Index (MBI), Expenditure.

\section{A. INTRODUCTION}

The government has made various efforts to increase and succeed in food diversification. The definition of food diversification is different in each policy. Food diversification is the diversification of food consumption to meet the nutritional needs of each individual. The implementation of food diversification requires proper study and research, where this food diversification is assumed to shift some of the carbohydrate sources from rice to non-rice commodities. The commodity referred to here is a local staple food. The average quality of food consumption in Indonesia is still low and less diversified, still dominated by carbohydrate sources, especially from grains [1].

People in developing countries, especially the poor, tend to consume more flour-containing food groups, such as rice, wheat, and corn, and fewer animal products, such as fresh fruits and vegetables [2] [3]. The diversity of food consumption is an effort to realize the adequacy of the nutrients needed by the body. This is based on the fact that no single food contains all the nutrients the body needs [4]. The more food groups consumed daily, the greater the chance of fulfilling the body's nutrients [5]. Therefore, it is necessary to diversify food consumption to minimize the risk of certain nutritional deficiencies due to consumption that relies only on certain foodstuffs. 
The higher the welfare of the people of a country, the smaller the share of food expenditure of the population and vice versa [6]. Based on Susenas data from March 2017, the percentage of households in Indonesia that share food expenditure to total expenditure in the poor category (more than $65 \%$ ) is $33.55 \%$. The high percentage of households with a large proportion of food expenditure indicates that the level of community welfare is relatively low. Differences in the structure of the economy, agriculture and economic development in each province will cause differences in households to diversify food which can be seen between types of regions (urban and rural), and between groups/strata of household income.

The increase in prices can make consumers to reduce their consumption or change the composition of food [7]. Thus, it is hoped that the research results will show that the right solution to improve consumer welfare is to switch to other food consumption or food diversification. However, the notion of food diversification in Indonesia is biased towards staple food (generally a source of carbohydrates). Government policies and programs are weak and limited to essential food diversification only [8]. The objectives to be achieved from this research are:

1. We are analyzing the level of household food diversification in Java.

2. We are analyzing the effect of per capita expenditure and food prices on food diversification in Java.

\section{B. METHOD}

This study uses 3 periods of SUSENAS data in Java, namely March 2015, March 2016 and March 2017. Respondents will be grouped into 4 groups based on income group. The Central Statistics Agency (BPS) distinguishes the income per capita of the population into 4 categories: 1) very high-income group, namely Q1 (average income per capita/month is more than Rp. 3,500,000), 2) high-income group, namely Q2 (average). The average income per capita/month is Rp. 3,500,000.00 to Rp. $2,500,000.00$ ), 3) the medium income group is Q3 (average income per capita/month is Rp. 2,500,000.00 to Rp. 1,500,000.00), and 4) low income group, namely Q4 (average income per capita/month is less than Rp. 1,500,000). The data used staple food data. The data were grouped into 12 groups, namely W1 (rice), W2 (corn), W3 (wheat flour), W4 (cassava), W5 (yam), W6 (fish), W7 (meat), W8 (eggs), W9 (vegetables), W10 (beans), W11 (fruits), and W12 (instant noodles).

Food diversification is an important quantitative aspect of food. The evaluation of household food diversity was measured using the Berry Index [9]. Although several indices measure variations in food consumption, the most appropriate alternative is the Berry index [10]. The Berry Index can be formulated as follows:

$$
B I_{i t}=1-\sum_{j=1}^{N} S_{i j t}^{2}(1)
$$

Where:

$\mathrm{BI}_{\mathrm{it}}=$ Berry index for the household $\mathrm{I}$ in year $\mathrm{t}$.

$S_{\text {et }}=$ share of expenditure for product $j$ in household expenditure I in year $t$.

The Berry Index has a value between 0 and 1 . If the BI value $=0$, it means that the household only buys one food product, and if $\mathrm{BI}=1$, it means that the household 
buys all types of food products included in SUSENAS. The level of food diversification can also be seen through the contribution of the daily calorie share of each commodity consumed. This will be estimated using modified equation 1, namely:

$$
M B I_{i}=1-\sum_{j=1}^{N} k_{i j}^{2}
$$

Where:

$\mathrm{MB}=$ Modified berry index for household $\mathrm{i}$

$\mathrm{K}_{\mathrm{ij}}=$ share of calories for product $j$ in household food expenditure $i$

The MBI value obtained by equation 2 can be compared with the 2017 Food Expectation Pattern (PPH) target. For the sake of comparing the BI and MBI values, equation (3) will be converted so that the equation becomes:

$$
M B I_{i}=\left(1-\sum_{j=1}^{N} k_{i j}^{2}\right) \div 0,7116 \text { (3) }
$$

If the $\mathrm{MBI}$ value $=0$, it means that the household only gets calorie intake from 1 type of food, and if $\mathrm{MBI}=1$, it means that the household has obtained its daily calorie intake following the $2017 \mathrm{PPH}$ target.

The effect of income and food prices on household diversification will be analyzed using multiple linear regression models as follows:

$$
B I_{i}=\mu_{0}+\mu_{1}\left(\frac{E X P_{i}}{A R T_{i}}\right)+\mu_{2} P_{1}+\cdots+\mu_{n} P_{n}+\mu_{n+1} A R T_{i}+\mu_{n+2} D_{w i l_{i}}+\epsilon_{i}
$$

Where:

$\mathrm{P}_{1}, \ldots, \mathrm{P}_{\mathrm{n}}=$ Food prices

$\mathrm{ART}_{\mathrm{i}}=$ Number of household members $\mathrm{i}$

D_wili $=$ Dummy area type $(0=$ rural, $1=$ urban $)$

$\epsilon_{\mathrm{I}}=$ Error

This model will be estimated using the ordinary least square (OLS) method.

\section{RESULT AND DISCUSSION}

\section{Household Expenditure and Consumption Patterns in Java}

The pattern of household consumption is highly dependent on the characteristics of the respondent's household. Previous research explains that differences in income (through the expenditure approach) will cause differences in selecting commodities or goods consumed by households. Other factors that are thought to influence consumption patterns apart from income are the number of family members, education, age and area of residence. The level of expenditure on food consumption (food share) can be used as an indicator to measure the level of household welfare. When household income is low, consumption expenditure is prioritized to meet basic needs, namely food consumption. Thus, it can be concluded that to diversify their food consumption, and households must adjust to the level of income they have. The higher the household income, the allocation of expenditure will shift from food expenditure to non-food expenditure. 
Table 1. Share of Food Expenditure and Number of Household Members by Income Group in 2015, 2016 and 2017

\begin{tabular}{cccccccccc}
\hline \multirow{2}{*}{ Year } & Region & \multicolumn{3}{c}{ Share food (\%) } & \multicolumn{4}{c}{$\begin{array}{c}\text { Number of Household } \\
\text { Members }\end{array}$} \\
\cline { 3 - 10 } & & Q1 & Q2 & Q3 & Q4 & Q1 & Q2 & Q3 & Q4 \\
\hline \multirow{2}{*}{2015} & Urban & 38,50 & 47,35 & 47,87 & 55,34 & 1,26 & 1,52 & 1,96 & 3,44 \\
& Rural & 45,32 & 55.25 & 56,91 & 60,58 & 1,30 & 1,28 & 1,47 & 3,27 \\
2016 & Urban & 25,67 & 36,14 & 43,00 & 54,77 & 2,89 & 2,99 & 3,14 & 3,77 \\
& Rural & 18,64 & 33,19 & 44,64 & 59,51 & 3,01 & 2,88 & 2,90 & 3,48 \\
& Urban & 23.91 & 33,86 & 29,96 & 50,98 & 2,89 & 2,86 & 3,13 & 3,79 \\
& Rural & 19,68 & 29,96 & 42,03 & 53,71 & 2,91 & 2,67 & 2,84 & 3,52 \\
\hline
\end{tabular}

Source: SUSENAS March 2015, 2016 and 2017 processed

In general, the average monthly income of households in Java is Rp. 1,759,147 (in 2015), Rp. 1,139,581.00 (in 2016) and Rp. 1,137,573.00 (in 2017). The income per capita of households in Java is still higher than the average national income. The share of household food in Java is $54.32 \%$ (in 2015), $53.82 \%$ (in 2016) and $49.02 \%$ (in 2017). If it is differentiated based on the type of area, it is known that the average per capita income in urban areas is much higher than in rural areas. The average number of family members in urban areas is less than in urban areas. The number of family members is thought to affect consumption patterns and food diversification. Urban and rural areas Share food from 2015 to 2017 has decreased (table 1). If the variable tastes caterisparibus, then by Engle's law states that the food share or the percentage of food expenditure will decrease with increasing income [11]. This is by table 1 , which shows food share in the Q1 $<$ Q2 $<$ Q3 $<$ Q4 groups.

Table 1 shows the average share of food expenditure in general for urban areas, households in the Q1 group from 2015 - 2017 have decreased. A decrease in food share indicates an increase in welfare. Indirectly, the share of food expenditure to total expenditure can be used as an indicator to measure the level of welfare [12]. The share of rice expenditure for consumption in Java has decreased from 2015 - 2017.

The level of diversification is measured using the Berry Index (Berry Index). Based on the share of household expenditure, the analysis results show that the Berry Index of urban and rural households for each income group is not much different (Table 2). The value of BI (table 2) and MBI (table 3) in urban and rural areas for each income group in Java Island has a fairly high level of food diversification, both from the type of food consumed and the source of calorie intake. The value of MBI is always greater than the value of BI for each income group, meaning that there is no concentration of calorie share in rice commodities. This is following the condition of the share of rice consumption which has decreased from year to year. The decrease in the share of rice consumption shows that there is a decrease in rice consumption and switch to other commodities that produce calories. 
Table 2. Household Berry Index (BI) and Modified Berry Index (MBI) Values

\begin{tabular}{|c|c|c|c|c|c|c|c|c|c|c|c|c|}
\hline \multirow{3}{*}{$\begin{array}{c}\text { level of } \\
\text { expendicture }\end{array}$} & \multicolumn{6}{|c|}{ Berry Indeks Value } & \multicolumn{6}{|c|}{ Modified Berry Indeks Value } \\
\hline & \multicolumn{2}{|c|}{2015} & \multicolumn{2}{|c|}{2016} & \multicolumn{2}{|c|}{2017} & \multicolumn{2}{|c|}{2015} & \multicolumn{2}{|c|}{2016} & \multicolumn{2}{|c|}{2017} \\
\hline & Urban & Rural & Urban & Rural & Urban & Rural & Urban & Rural & Urban & Rural & Urban & Rural \\
\hline $\mathrm{Q} 1$ & 0,97 & 0,95 & 0,95 & 0,94 & 0,96 & 0,95 & 1,23 & 1,17 & 1,28 & 1,23 & 1,20 & 1,12 \\
\hline Q2 & 0,96 & 0,95 & 0,95 & 0,94 & 0,96 & 0,95 & 1,20 & 1,14 & 1,18 & 1,11 & 1,18 & 1,11 \\
\hline Q3 & 0,95 & 0,93 & 0,95 & 0,95 & 0,96 & 0,96 & 1,19 & 1,09 & 1,24 & 1,22 & 1,13 & 1,09 \\
\hline Q4 & 0,93 & 0,91 & 0,94 & 0,93 & 0,95 & 0,93 & 1,10 & 1,10 & 1,15 & 1,09 & 0,96 & 0,96 \\
\hline
\end{tabular}

2. The Effect of Food Expenditure and Prices on Household Food Diversification in Java.

Analysis of the effect of food expenditure and prices on household food diversification in 2015 - 2017 was carried out using a multiple linear regression model where the parameter estimation method was Ordinary Least Square (OLS). The pvalue of the heteroscedasticity test results is 0.00 and is smaller than alpha (0.05), so it can be said that the error does not have a homogeneous variance. Simultaneous test results with the $\mathrm{F}$ statistic produce a p-value of 0.00 and smaller than alpha (0.05). It can be said that the independent variables together affect the level of household food diversification in Java.

Based on table 4 shows the results of the regression based on the expenditure group per capita per month. The analysis results for households in the Q1 and Q2 groups of expenditure variables have an estimated parameter of 0.0000 . This means that an increase in per capita expenditure of 10.00 per cent will not increase or decrease the level of diversification. This indicates that the increase in household income or expenditure in Q1 and Q2 does not impact diversification. For the Q1 group, the variables P1, P4, P5, P6, P7, P9, P10 and P11 have a negative estimation parameter sign, meaning that a price increase will reduce the level of diversification. An increase in the number of household members will reduce the level of diversification. The regional dummy variable has an estimated parameter of -0.0095 , meaning that rural households have an average food diversification level of 0.0095 per cent higher than urban households. For group Q2, the variables P1, P2, P4, P6, P7, P9, P10 and P11 have a negative estimation parameter sign. An increase in the number of household members will increase the level of diversification. The region dummy variable has an estimated parameter of -0.0095 . This value indicates that households in rural areas have an average level of food diversification 0.0089 per cent higher than households in urban areas. 
Table 4. Effect of Food Expenditure and Prices on Household Food Diversification (Independent Variable is BI)

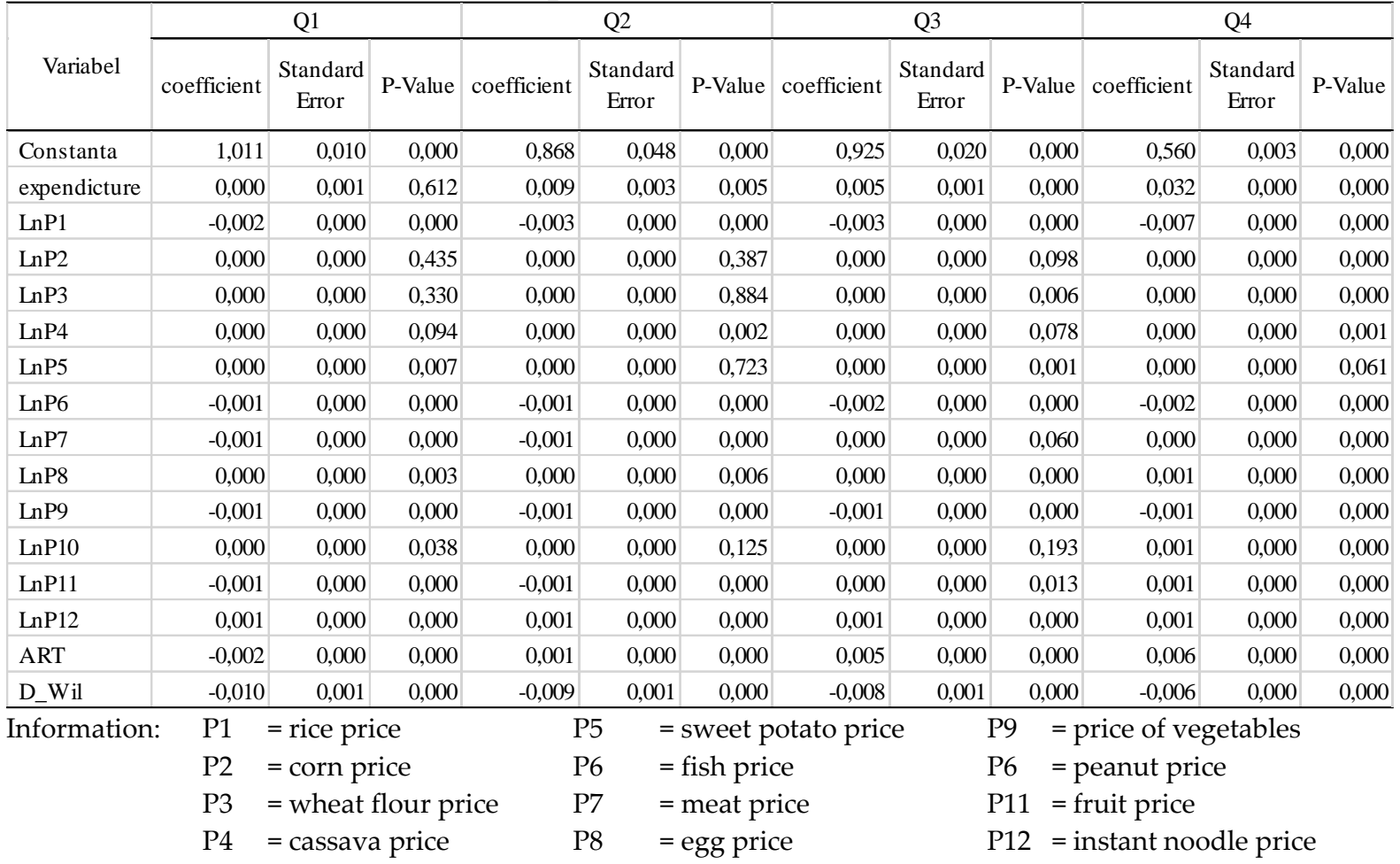

The analysis results for the income group Q3 and the income group Q4 the expenditure variable has estimated parameters of 0.0049 and 0.0317 . This means that an increase in per capita expenditure of 10.00 per cent will increase the level of diversification by 0.049 per cent (Q3) and 0.317 per cent (Q4). For Q3, the variables P1, P2, P4, P6, P7, P9, P11 have a negative parameter sign, meaning that a price increase reduces diversification. An increase in the number of household members will increase the level of diversification. The regional dummy variable has an estimated parameter of -0.0081 . This value indicates that rural households have an average level of food diversification 0.0081 per cent higher than urban households. For Q4, the price variable has a positive estimation sign, meaning that a price increase will increase food diversification. Low-income groups are very sensitive to changes in food prices. If there is an increase in food prices, the household will replace consumption with other secondary foods [13] [14]. An increase in the number of household members will increase the level of diversification. The regional dummy variable has an estimated parameter of -0.0062 . This value indicates that households in rural areas have an average level of food diversification 0.0062 per cent higher than households in urban areas.

\section{CONCLUSION}

The share of household food expenditure in urban and rural areas of more than 50 per cent is for households in the Q3 and Q4 groups. This means that the food security of households in the Q3 and Q4 groups is still low. The household food diversification of groups Q1 and Q2 are greater than that of groups Q3 and Q4. Food 
diversification is influenced by per capita expenditure in Q3 and Q4 households, while for Q1 and Q2 households, per capita expenditure does not affect food diversification. The policy of food diversification, namely food diversification, needs to pay attention to the commodities offered, where the results of the study show an increase in the share of food expenditure for wheat flour commodities. Wheat flour is an imported commodity, where Indonesia does not produce wheat flour.

\section{ACKNOWLEDGEMENTS}

The authors thank the LPDP for the BUDI-DN scholarship program, which has sponsored the costs of the author's lectures and research during his doctoral education at IPB. The authors also thank BPS for providing the data used for the research.

\section{REFERENCES}

[1] Rachman, H. P. S. \& Ariani, M. (2016). Penganekaragaman Konsumsi Pangan di Indonesia. Kementrian Pertan RI, 6(2), 140-154.

[2] Mekuria, G., Wubneh, Y., \& Tewabe, T. (2017). Household dietary diversity and associated factors among residents of finote selam town, north west Ethiopia: A cross sectional study. BMC Nutr., 3(1), 3-8. doi: 10.1186/s40795-017-0148-0.

[3] Ruel, M. T. (2003). Operationalizing Dietary Diversity: A Review of Measurement Issues and Research Priorities. J. Nutr, 133(May), 3875-3878. doi: https://doi.org/10.1093/jn/133.11.3911s.

[4] Suryana, A. (2008). Penganekaragaman Konsumsi Pangan dan Gizi Faktor Pendukung Peningkatan Kualitas Sumber Daya Manusia. Pangan, 17(52), 3-12. doi: https://doi.org/10.33964/jp.v17i3.262.

[5] Labadarios, D., Steyn, N. P., \& Nel, J. (2011). How diverse is the diet of adult South Africans ?. Nutr. J., 10(1). doi: 10.1186/1475-2891-10-33.

[6] Deaton, A., \& Muellbauer, J. (1980). An Almost Ideal Demand System. Am. Econ. Rev., vol. 70(3), 312-326.

[7] Anríquez, G., Daidone, S., \& Mane, E. (2013). Rising food prices and undernourishment: A cross-country inquiry. Food Policy, 38(1), 190-202. doi: 10.1016/j.foodpol.2012.02.010.

[8] Ariani, M. (2010). Analisis Konsumsi Pangan Tingkat Masyarakat Mendukung Pencapaian Diversifikasi Pangan. Gizi Indones., 33(1), 20-28. doi: 10.36457/gizindo.v33i1.84.

[9] Alexandri, C., Luca, L., \& C. Kevorchian, C. (2014). "Subsistence Economy and Food Security - The Case of Rural Households from Romania. Procedia Econ. Finance., 22(November), 672-680. doi: 10.1016/s2212-5671(15)00282-8.

[10] Thiele, S., \& Weiss, C. (2003). Consumer demand for food diversity: Evidence for Germany. Food Policy, 28(2), 99-115. doi: 10.1016/S0306-9192(02)00068-4.

[11] Nicholson, W. (1995). Mikroekonomi Intermediate dan Aplikasinya. Jakarta: Binarupa Aksara.

[12] Maxwell, D., Levin, C., Armar-Klemesu, M., Ruel, M., Morris, S., \& Ahiadeke, C. (2000). Urban livelihoods and food and nutrition security in Greater Accra, Ghana. 
[13] Jensen, H. H., \& Manrique, J. (1998). Demand for food commodities by income groups in Indonesia. Appl. Econ., 30(4), 491-501. doi: 10.1080/000368498325750.

[14] Muhammad, A., Seale, J. L., Meade, B., \& Regmi, A. (2014). International evidence on food consumption patterns: An update using 2005 international comparison program data. Int. Food Consum. Patterns Glob. Drivers Agric. Prod., 1-104. doi: 10.2139/ssrn.2114337. 